\title{
PREOPERATIVE EVALUATION OF THE SCORING SYSTEM DEVELOPED BY ATEMA TO DISTINGUISH COMPLICATED FROM UNCOMPLICATED ACUTE APPENDICITIS
}

\author{
By
Abd El-Kader Hamdy Mohammed Abd El-Kader, Mohammed Hafez Mahmoud and Mahmoud Abd El-Hady Abd El-Aziz \\ Department of General Surgery, Faculty of Medicine, Al-Azhar University (Cairo) \\ Corresponding author: Abd El-Kader Hamdy Mohammed Abd El-Kader, \\ Mobile: (+20) 1099099864, E-mail: dr.surgeon100100@gmail.com
}

\begin{abstract}
Background: The diagnosis of acute appendicitis is purely based on history, clinical examination and some laboratory investigations (e.g. WBC count). Certain diagnosis can only be obtained at surgery and after pathological examination of surgical specimen. The Atema scoring system can distinguish complicated from non-complicated appendicitis preoperatively.

Objective: To evaluate the validity and diagnostic accuracy of the Atema scoring system in differentiating complicated from non- complicated appendicitis before surgery.

Patients and Methods: A prospective study was carried out on 60 patients complaining of acute abdominal pain, diagnosed as acute appendicitis using the Alvarado score and undergoing open appendectomy operation in the Emergency Department, Faculty of Medicine, Al-Azhar University from December 2019 to July 2020. Routine clinical and laboratory work up were done, the Atema Score was calculated to every patient in the study preoperatively. The decision to operate was made by a senior surgeon (consultant). The intraoperative finding whether the acute appendicitis was complicated or not was recorded. Post operatively, the histo-pathological examination results were recorded for each patient. The ROC curve was done, the cut-off point of the Atema scoring system was detected based on the ROC curve. The area under the ROC curve and the p-value were calculated. The sensitivity, specificity, positive predictive value and negative predictive value of the Atema scoring system above the level of the cut-off point were calculated.
\end{abstract}

Results: In total of 60 patients, 37 patients (61.7\%) had complicated appendicitis and 23 patients $(38.3 \%)$ had non-complicated appendicitis. The sensitivity of the Atema score has a diagnostic accuracy of 0.944 (Area under the curve) with sensitivity $86.96 \%$ and specificity $89.19 \%$ with positive predictive value $83.3 \%$ and negative predictive value $91.7 \%$.

Conclusion: The Atema score can significantly differentiate between complicated and noncomplicated acute appendicitis. A higher score denotes increased probability of the presence of complications as perforation and gangrene.

Keywords: Atema scoring system, complicated acute appendicitis, uncomplicated acute appendicitis, Appendectomy. 


\section{INTRODUCTION}

In 1886, Reginald Fitz from Boston first identified inflammation of the appendix as a cause of right lower quadrant pain. $\mathrm{He}$ coined the term appendicitis and recommended early surgical intervention. Robert Lawson performed first appendectomy in 1735 in England. Now 130 years later, acute appendicitis still remains one of the most common abdominal emergencies, demanding surgery (Liu and Fogg, 2011).

The importance of the vermiform appendix stems from its tendency to inflammation which results in the syndrome called acute appendicitis (Norman et al., 2018).

Acute appendicitis, the most common abdominal emergency that requires surgical treatment; it shows a lifetime risk of $7 \%$. Its overall incidence is approximately 11 cases per 10,000 individuals per year, and may occur at any age, although it is relatively rare at the extremes of age (D'Souza and Nugent, 2016).

Acute appendicitis is the most common cause of acute abdomen in young adults. Appendicitis is sufficiently common that appendectomy is the most frequently performed urgent abdominal operation and is often the first major procedure performed by a surgeon in training (Norman et al., 2018).

While the clinical diagnosis may be straightforward in patients presenting with the classic signs and symptoms of the disease, atypical presentations may result in diagnostic confusion and delay in treatment (Glass et al., 2016).
Advances in modern radiographic imaging have improved the diagnostic accuracy, however, the diagnosis of appendicitis remains essentially clinical, requiring a mixture of observation, clinical acumen and surgical science and as such it remains an enigmatic challenge and a reminder of the art of surgical diagnosis (Norman et al., 2018).

The present work aimed to evaluate the validity and diagnostic accuracy of the Atema scoring system in differentiating complicated from non-complicated appendicitis before surgery.

\section{PATIENTS AND METHODS}

A prospective outcome analysis was done for 60 patients who were candidates for surgical excision complaining of acute abdominal pain and diagnosed as acute appendicitis depending on Alvarado score and undergoing open appendectomy in the Emergency Department of Faculty of Medicine, Al-Azhar University Hospitals from December 2019 to July 2020. History taking, Clinical Examination, laboratory work up and imaging (pelviabdominal ultrasound or pelvi-abdominal computed tomography) were done to the population of the study according to Alvarado and Atema scoring systems. The decision to operate was taken by general surgery specialist based on the clinical and laboratory findings and the scoring systems.

\section{Inclusion criteria:}

Patients fulfilling the following criteria were included in the study: Age (14-60), females and males and clinical suspicion for acute appendicitis. 


\section{Exclusion criteria:}

Patients were excluded from the study according to the following criteria: Patients with no clinical suspicion for acute appendicitis, vitally unstable patients (sepsis or septic shock), previous abdominal operations, pregnancy, patient who refuse to participate in the study, chronic appendicitis, child below 14 years, morbid obesity and other comorbidities.

All candidates were subjected to proper history taking, proper physical examination, laboratory investigations: total leucocytic count and $\mathrm{C}$ - reactive protein level, complete blood count with differential count, liver and renal function tests, blood sugar and coagulation profile, in addition to urine analysis to exclude urinary tract infection), radiological investigations (Pelvi-abdominal ultrasound or pelvi-abdominal computed tomography was done to check for extraluminal free air, peri- appendicular fluid and appendicolith), scoring systems (All patients with suspected acute appendicitis had their Alvarado and Atema score calculated) and histopathological examination was done to every specimen.

\section{Statistical methods:}

Pre-coded data was entered on the computer using the statistical package of social science software program version 2.1 (SPSS) to be statistically analysed. Data was summarized using: Mean and standard deviation for quantitative variables. Number and percent for qualitative variables. Comparison between quantitative variables was done using $\mathrm{T}$ test for normally distributed variables and non-parametric Mann- Whitney test for variables that were not normally distributed. ROC (Receiver Operator characteristic) curve was used to find out the best cut off point in the Atema score to differentiate complicated from noncomplicated acute appendicitis. The sensitivity and specificity for the Atema score higher than the cut-off point were calculated.

\section{RESULTS}

$37(61.7 \%)$ of the studied patients were males, while $23(38.3 \%)$ were females. The type of imaging done was either pelvi-abdominal ultrasonography or pelvi abdominal computed tomography. Regarding patients who had the symptoms for less than 48 hours, 94.7\% had noncomplicated appendicitis and regarding patients who had the symptoms for $\geq 48$ hours, $100 \%$ had complicated appendicitis (Table 1). 
Table (1): Sex, type of imaging, duration of symptoms and groups of patients

\begin{tabular}{|c|c|c|}
\hline & $\mathbf{N}$ & $\%$ \\
\hline \multicolumn{3}{|l|}{ Sex } \\
\hline Male & 37 & 61.70 \\
\hline Female & 23 & 38.30 \\
\hline \multicolumn{3}{|l|}{ Imaging done } \\
\hline CT scan & 2 & 3.30 \\
\hline Ultrasound & 58 & 96.70 \\
\hline \multicolumn{3}{|l|}{ Duration of symptoms } \\
\hline 24 hours & 38 & 63.30 \\
\hline 48 hours & 22 & 36.70 \\
\hline \multirow{2}{*}{$\begin{array}{l}\text { Groups of patients } \\
\text { according to symptoms }\end{array}$} & Complicated appendicitis & Non complicated appendicitis \\
\hline & \begin{tabular}{l|l}
$\geq 48$ hours & $100 \%$ \\
\end{tabular} & \begin{tabular}{l|l}
$<48$ hours & $94.7 \%$ \\
\end{tabular} \\
\hline
\end{tabular}

Regarding patients who are younger than 45 years old, $59.6 \%$ had noncomplicated appendicitis. While regarding patients who were 45 years old or older, $50 \%$ had complicated appendicitis. Regarding patients with temperature 37 degrees or less, $92.3 \%$ had noncomplicated appendicitis and regarding patients with temperature $\geq 38$ degrees, $100 \%$ had complicated appendicitis. Regarding patients who had a white cell count $<13000$ cells $/ \mathrm{mm}^{3}, 72.7 \%$ had noncomplicated appendicitis and regarding patients who had a white cell count $\geq$ 13000 cells/ $\mathrm{mm}^{3}, 55.5 \%$ had complicated appendicitis. Regarding patients who had their CRP below $50 \mathrm{mg} / \mathrm{l}, 68.75 \%$ had non complicated appendicitis while $31.25 \%$ had complicated appendicitis, regarding patients with CRP between $50 \& 100 \mathrm{mg} / \mathrm{l}$, $66.6 \%$ had non-complicated appendicitis while $33.4 \%$ had complicated appendicitis and regarding patients with CRP above $100 \mathrm{mg} / \mathrm{l}, \quad 52.7 \%$ had complicated appendicitis while $47.3 \%$ had noncomplicated appendicitis (Table 2).

Table (2): Age, temperature, WBCs and CRP among studied cases and groups of patients

\begin{tabular}{|c|c|c|c|c|}
\hline & Mean \pm SD & Median (IQR) & Minimum & Maximum \\
\hline Age (years) & $30.7 \pm 12.2$ & $28.5(9.5: 37)$ & 18 & 60 \\
\hline Temperature & $37.6 \pm 1.5$ & $37.5(37.5: 38.5)$ & 27.5 & 38.9 \\
\hline WBCs & $12.9 \pm 4.6$ & $12.4(9.2: 16.73)$ & 4.6 & 25.8 \\
\hline CRP & $88.2 \pm 84.1$ & $49(20.3: 141)$ & 1 & 307 \\
\hline $\begin{array}{l}\text { Groups of patients } \\
\text { according to }\end{array}$ & \multicolumn{2}{|c|}{ Non complicated appendicitis } & \multicolumn{2}{|c|}{ Complicated appendicitis } \\
\hline Age (years) & $<45$ & $59.6 \%$ & $>45$ & $50 \%$ \\
\hline Temperature & $\leq 37$ & $92.3 \%$ & $\geq 38$ & $100 \%$ \\
\hline WBCs & $\begin{array}{c}<< \\
13000 \text { cells } / \mathrm{mm}^{3}\end{array}$ & $72.7 \%$ & $\begin{array}{c}\geq \\
13000 \text { cells } / \mathrm{mm}^{3}\end{array}$ & $55.5 \%$ \\
\hline \multirow{3}{*}{ CRP } & $<50 \mathrm{mg} / \mathrm{l}$ & $68.75 \%$ & $<50 \mathrm{mg} / \mathrm{l}$ & $31.25 \%$ \\
\hline & $\begin{array}{c}\text { Between } 50 \& \\
100 \mathrm{mg} / 1\end{array}$ & $66.6 \%$ & $\begin{array}{c}\text { Between } 50 \& \\
100 \mathrm{mg} / \mathrm{l}\end{array}$ & $33.4 \%$ \\
\hline & Above $100 \mathrm{~m} / \mathrm{l}$ & $47.3 \%$ & Above $100 \mathrm{~m} / \mathrm{l}$ & $52.7 \%$ \\
\hline
\end{tabular}


Regarding patients who had periappendicular fluid on imaging, $71.4 \%$ had complicated appendicitis and regarding patients who didn't have periappendicular fluid on imaging, 64\% had non-complicated appendicitis. The scoring system developed by Atema and was used on the study population included to different scoring systems for the patients that underwent ultrasound scan and the patients that underwent computed tomography scan (Table 3).

Table (3): Peri-appendicular fluid on imaging of the patient, the presence of appendicolith on imaging of the patients and groups of patients

\begin{tabular}{|l|c|c|}
\hline & N & \% \\
\hline $\begin{array}{l}\text { Peri-appendicular fluid on } \\
\text { imaging }\end{array}$ & & 51.70 \\
\hline No & 31 & 48.30 \\
\hline Yes & 29 & 95.00 \\
\hline Appendicolith on Imaging & 57 & 5.00 \\
\hline No & 3 & Complicated appendicitis \\
\hline Yes & $\begin{array}{c}\text { Non complicated } \\
\text { appendicitis }\end{array}$ & $64 \%$ \\
\hline $\begin{array}{l}\text { Groups of patients according } \\
\text { to peri-appendicular fluid on } \\
\text { imaging }\end{array}$ & $71.4 \%$ & \\
\cline { 2 - 3 }
\end{tabular}

In our study, the operative findings were that $38.3 \%$ of cases were complicated and $61.7 \%$ of patients were non-complicated (Table 4).

Table (4): The relation between the Atema score and intra operative findings

\begin{tabular}{|l|c|c|c|c|c|}
\hline \multirow{2}{*}{ patients } & \multicolumn{2}{|c|}{ Non complicated } & \multicolumn{2}{c|}{ Complicated } & \multirow{2}{*}{ P value } \\
\cline { 2 - 4 } & Mean \pm SD & $\begin{array}{c}\text { Median } \\
(\mathbf{I Q R})\end{array}$ & Mean \pm SD & $\begin{array}{c}\text { Median } \\
(\mathbf{I Q R})\end{array}$ & \\
\hline $\begin{array}{l}\text { Atema Score and } \\
\text { intraoperative findings }\end{array}$ & $4.7 \pm 2.4$ & $4(2: 6)$ & $11.9 \pm 3.6$ & $13(8: 15)$ & $<0.001$ \\
\hline Atema Score & $7.5 \pm 4.5$ & $6.0(4: 11.0)$ & & & \\
\hline \multirow{2}{*}{$\begin{array}{l}\text { Groups of patients } \\
\text { according to operative } \\
\text { findings }\end{array}$} & $\begin{array}{c}\text { Non } \\
\text { complicated } \\
\text { appendicitis }\end{array}$ & $\begin{array}{c}\text { Complicated } \\
\text { appendicitis }\end{array}$ & & & \\
\cline { 2 - 3 } & $61.7 \%$ & $38.3 \%$ & & & \\
\hline
\end{tabular}

In the study performed by Atema on the atema scoring system in 2015, regarding patients who underwent ultrasound scan, the cut-off point of the Atema scoring system was found to be 7 , while regarding patients who underwent CT scan, the cut-off point was found to be 6. In our study, the $\mathrm{p}$ value was $<0.001$ (Figure 1) (Table 5).

Table (5): The relation between the intraoperative findings and the cut-off point

\begin{tabular}{|c|c|c|c|c|c|}
\hline Intraoperative findings & \multicolumn{2}{|c|}{$\begin{array}{c}\text { Non } \\
\text { Complicated }\end{array}$} & \multicolumn{2}{c|}{ Complicated } & \multirow{2}{*}{ p value } \\
\cline { 1 - 5 } Atema Score & $\mathbf{N}$ & $\mathbf{\%}$ & $\mathbf{N}$ & $\mathbf{\%}$ & \\
\cline { 1 - 5 }$<7$ & 28 & 75.70 & 3 & 13.00 & \multirow{2}{*}{$<0.001$} \\
\hline$\geq 7$ & 9 & 24.30 & 20 & 87.00 & \\
\hline
\end{tabular}


In our study, the sensitivity of the Atema score above the cut-off point was $86.96 \%$ while the specificity was $89.19 \%$ (Table 6 and fig.1)

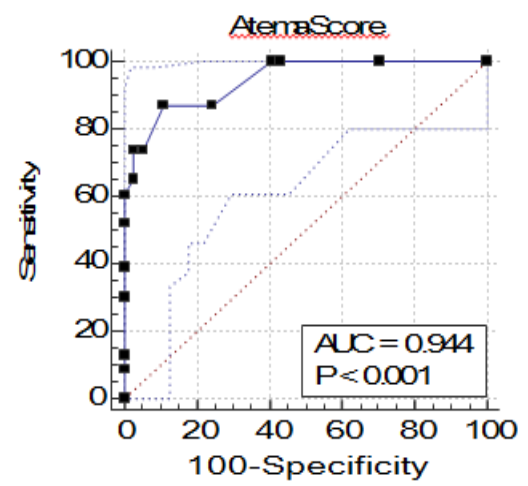

\begin{tabular}{|c|c|}
\hline Area under the ROC curve (AUC) & 0.944 \\
\hline p value & $<0.001$ \\
\hline
\end{tabular}

Figure (1): The AUC and the p-value

Table (6): The sensitivity and the specificity of the Atema score above the cut-off point

\begin{tabular}{|c|c|c|c|c|}
\hline Atema score & Sensitivity & Specificity & +PV & -PV \\
\hline$>7$ & 86.96 & 89.19 & 83.3 & 91.7 \\
\hline
\end{tabular}

Histopathological examination was done to every specimen (Table 7).

Table (7): Results of histopatholgoical examination

\begin{tabular}{|l|c|}
\hline & No. (\%) \\
\hline Non Complicated & $37(61.6 \%)$ \\
\hline Complicated & \\
Gangeranous & $20(33.3 \%)$ \\
Perforated & $3(5.1 \%)$ \\
\hline
\end{tabular}

\section{DISCUSSION}

Acute appendicitis, the most common abdominal emergency that requires surgical treatment, shows a lifetime risk of $7 \%$. Its overall incidence is approximately 11 cases per 10,000 individuals per year, and may occur at any age, although it is relatively rare at the extremes of age. Between 15 and 30 years of age there is an increase of 23 cases per 10,000 of the population per year, and then a decline of cases with aging (Siddiqui et al., 2018).

In the present study, the scoring system developed by Atema to distinguish uncomplicated from complicated appendicitis is evaluated. The score was based on patient characteristics and diagnostic markers that are collected routinely in clinical practice, combined with features from imaging. As CT and ultrasonography are both currently used to 
diagnose acute appendicitis, two separate scoring systems was developed, one incorporating CT features and one based on ultrasound features. The sex distribution was $61.7 \%$ males to $38.3 \%$ females showing male predominance in the incidence of acute appendicitis.

Abbasi et al. (2017) stated that $61 \%$ were males, and $39 \%$ were females, showing male predominance in the incidence of acute appendicitis.

Alnjadat and Abdallah (2013) showed male predominance in the incidence of acute appendicitis. Nanjundaiah et al. (2014) in their study found that among their patients there were $61.6 \%$ male patients and $38.4 \%$ female patients showing male predominance in the incidence of acute appendicitis. In (2015), Atema et al. performed a study on the Atema score and found that the sex distribution showed male predominance in the incidence of acute appendicitis. In (2017), Raja et al. performed a study on the value of $\mathrm{C}$ reactive protein in enhancing the diagnosis of acute appendicitis and found that provisional evidence that very high CRP may be related to necrotizing appendicitis, while CRP above $40 \mathrm{mg} / \mathrm{L}$ may suggest supportive or inflammatory appendicitis.

In our study, the mean age of the population was 30.7 with a standard deviation (SD) of 12.2 years ranging from 18 to 60 years. Regarding patients who were younger than 45 years old, $59.6 \%$ had non-complicated appendicitis and regarding patients who were 45 years old or older, $50 \%$ had complicated appendicitis. In the study developed by Atema et al. (2015) on the Atema score in 2015, regarding patients who underwent ultrasound scan, the sensitivity of the Atema scoring system above the cut-off point was $96.6 \%$ while the specificity was $45.7 \%$.

In our study, we found that the positive predictive value of the Atema scoring system above the cut-off point was $83.3 \%$, while the negative predictive value was $91.7 \%$.

In the study performed by Atema et al. (2015) on the Atema score, it was found that regarding patients who underwent ultrasound scan, the positive predictive value of the Atema scoring system was $41.6 \%$ while the negative predictive value was $97.1 \%$, and regarding the patients who underwent CT scan, the positive predictive value was $55.2 \%$ while the negative predictive value was $94.7 \%$.

\section{CONCLUSION}

The Atema scoring system can significantly differentiate complicated from non-complicated appendicitis in the Egyptian population.

\section{ACKNOWLEDGMENT}

I would like to thank Prof. Dr. Tawakol Gamil, Professor of Clinical Pathology at Mansoura University, for his help in revising the histopathological specimens.

\section{REFERENCES}

\section{Abbasi AS, Niaz $S$ and Ashfaq $U$ (2017): Acute Appendicitis:} Relationship of Total Leucocyte Count with Per-Operative Stage. Journal of Islamabad Medical \& Dental College; 6(4):255-8.

2. Abbas PI, Zamora IJ, Elder SC, Brandt ML, Lopez ME and Orth RC (2016): How Long Does it Take to 
Diagnose Appendicitis? Time Point Process Mapping in the Emergency Department. Pediatr Emerg Care, 9: 45.

3. Alnjadat I and Abdallah B (2013): Alvarado versus RIPASA score in diagnosing acute appendicitis. Rawal Medical Journal; 38(2):147-51.

4. Ansaloni L, Catena F, Coccolini F, Ercolani G, Gazzotti F, Pasqualini E and Pinna AD (2011): Surgery versus conservative antibiotic treatment in acute appendicitis: a systematic review and meta-analysis of randomized controlled trials. Dig Surg; 28:210-221

5. Antoniou SA, Koch OO, Antoniou GA, Lasithiotakis K, Chalkiadakis GE, Pointner R and Granderath FA (2014): Metaanalysis of randomized trials on single-incision laparoscopic versus conventional laparoscopic appendectomy. Am J Surg; 207:613622.

6. Atema JJ, Van Rossem CC, Leeuwenburgh MM, Stoker $J$ and Boermeester MA (2015): Scoring system to distinguish complicated from non-complicated acute appendicitis. BJS, 102(8):979-980.

7. D'Souza N and Nugent $K$ (2016): Appendicitis. Am Fam Physician; 93: 142- 143.

8. Glass CC, Saito JM, Sidhwa F, Cameron DB, Feng C, Karki M, Abdullah F, Arca MJ, Goldin AB, Barnhart DC and Zurakowski D (2016): Diagnostic imaging practices for children with suspected appendicitis evaluated at definitive care hospitals and their ssociated referral centers. J Pediatr Surg, 7: 8-10.

9. Liu K and Fogg L (2011): Use of antibiotics alone for treatment of uncomplicated acute appendicitis: a systematic review and meta-analysis. Surgery, 150(4):673-83.

10. Nanjundaiah N, Mohammed A, Shanbhag V, Ashfaque $K$ and Priya SA (2014): A comparative study of RIPASA score and ALVARADO score in the diagnosis of acute appendicitis. Journal of clinical and diagnostic research: JCDR, 8(11):NC03.

11. Norman SW, O'Connell $P$ and Andrew W (2018): McCaskie. Baily and Love's Short practice of surgery, 27th edition. HK Lewis, Great Britain; 11(72):1299.

12. Raja MH, Elshaikh E, Williams L and Ahmed MH (2017): The value of CRP in enhancing the diagnosis of acute appendicitis. Journal of Current Surgery 15 (7): 50-61.

13. Siddiqui J, Oliphant $\mathbf{R}$ and Suen M (2018): Appendicitis: A Traumatic Etiology. Journal of Case Reports, 8(3):176-8.

14. Xu AM, Huang $L$ and $L i$ TJ (2015): Single-incision versus threeport laparoscopic appendectomy for acute appendicitis: systematic review and meta-analysis of randomized controlled trials. Surg Endosc, 29:822843. 


\section{تقييم لنظام العد القياسي الذي أسسه أتيما للتفرقة بين إلتهاب الزائدة الدودية

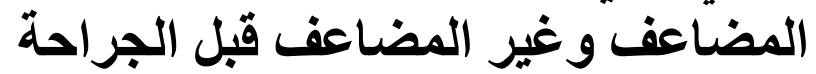

عبد القادر حمدي محمد عبد القادر، محمد حافظ محمود، محمود عبد الهادي عبد العزيز قسم الجراحة العامة، كلية الطب، جامعة الأزهر

E-mail: dr.surgeon100100@gmail.com

خلفيــة البــــث: إلتهاب الز ائدة الدودية الحاد هو واحد من حالات الطــــوارئ الجر احية الأكثر شيوعامع إنتشار مدي الحياة. ويستند تشخيص إلتهاب الزائدة الدودية الحاد علي أساس التاريخ المرضي والكثف السريري وبعض الفحوص المختبرية.

الهـــف مــن البحــث: اجريت هذه الدراسة الاستباقية لتقييم قدرة نظام العد القياسي أتيما علي التفرقة بين

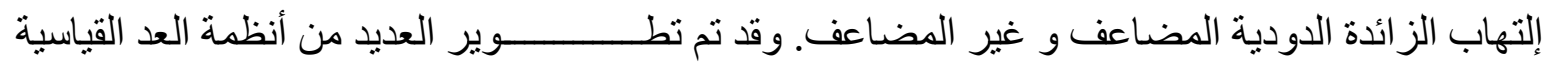
لتشخيص المرضي الذين يعانون من إلتهاب الزائدة الدودية الحاد، ومنهم كان نظام ألفا رادو هو أكثر شعبية، كما نظام العد القياسي أتيما للتفرقة بين إلتهاب الزائدة الدودية المضاعف و غير المضاعف. المرضــي وطـرق البحـث: اجريت هذه الدر اسة الإستباقية لتقييم قدرة نظام العد القياسي اتيما علي التفرقة

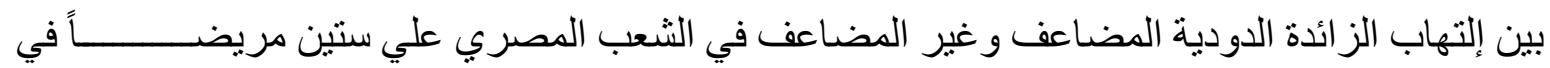
مستشفيـات جامعــة الأزهـر و علي مدار سبعــة أثهر ـ ويستند تشخيص إلتهاب الز ائدة الدودية الحاد علي أساس التاريخ المرضي و الكثف السريري وبعض الفحوص المختبرية.

نتـائج البحــث: نظام العد القياسي أتيما لديه دقة تشخيصية عالية وهو قادر بشكل ملحوظ علي التفرقة بين إلتهاب الزائدة الدودية المضاعف وغير المضاعف يعتمد نظام العد القياسي اتيما علي التاريخ المرضي و الفحص السريري و التحاليل الطبية والاشعة. وبالتالي من السهل حسابه ويمكن تطبيقه بسر عة.

الإســــــتنتاج: التشخيص الخاطئ و التأخر في الجر احة يمكن ان يؤدي الي مضـاعفات منل الغرغريناو الانتقاب واخير ا إلتهاب الغشاء البيريتوني. الصعوبة في التشخيص تظهر في صغار السن وكبار السن و النساء في سن الانجاب لان لديهم عادة اعـر اض غير نمطية والعديد من الحالات الاخري الموجودة التي لاديها اعــــر اض مثل إلتهاب الزائدة الدودية و الابحاث العلمية تظهر ان \% 7 - 2 من البالغين عند إجراء عمليات استكثـاف للبطـــن يكون لاديهم أمـــر اض أخري غير إلتهاب الزائدة الدودية. التفرقة المبكرة بين إلتهاب الز ائدة الدودية المضاعف و غير المضاعف أمر أساسي في تحديد كيفية العلاج. 